\title{
The Social Dimension of Higher Education In Albania
}

\author{
Juljana Laze, PhD candidate \\ University "Aleksander Moisiu" Durres, Faculty of Education, \\ Sociology Department, Lecturer in social science disciplines \\ E-mail: julilaze@gmail.com
}

\section{Doi:10.5901/jesr.2013.v4n3p299}

\begin{abstract}
The reform of higher education in Albania has been on the agenda of universities cooperation for a long time. It emphasized that:"universities are key players in Europe's future and for the successful transition to a knowledge-based economy and society. In the political debate on the future of higher education, the social dimension has become increasingly important. The universities are required to establish incentives so that higher education institutions accept more non-traditional learners and improve the learning environment. This approach links the modernization of higher education to the achievement of economic and social goals in a knowledge-based economy. Social dimension in the Albania Higher Education is significant changed, but the challenges remain. This paper has on its focus the analysis in particular:1)How the social dimension of higher education is understood in Albania Higher Education.2) How are the policy of education linked on the social dimension to the Bologna commitment.3) What are the specific targets to improve the participation of under-represented groups in higher education, where only about half of the Bologna countries systematically monitor their participation? The analysis showed that, at European level, significant attention is devoted to making European Higher Education more equitable and inclusive. In particular, what has been done at national level to make higher education systems more inclusive?
\end{abstract}

Keywords: Social dimension, Incentives, Challenge, Educational reform.

\section{Introduction}

In recent years, the concept of the social dimension has been at the centre of many important policy documents at international level. They all assert that the social dimension of higher education is primarily concerned with providing opportunities for all members of a society to participate in higher education. Since 2007, within the Bologna process, the "social dimension" is understood as the process towards achieving this overarching goal (BFUG 2007, p. 11) - and thus as a large sphere of activities where governments can enact policies ${ }^{1}$.

In the European Union, the Council conclusions of 11 May 2010 define the social dimension as:

"equal opportunities for access to quality education, as well as equity in treatment, including adapting provisions to individuals' needs", whereby "equitable education and training systems ... are aimed at providing opportunities, access, treatment and outcomes that are independent of socio-economic background and other factors which may lead to educational disadvantage"2.

In the European Union, the Council conclusions of 11 May 2010 define the social dimension as:

"equal opportunities for access to quality education, as well as equity in treatment, including adapting provisions to individuals' needs", whereby "equitable education and training systems ... are aimed at providing opportunities, access, treatment and outcomes that are independent of socio-economic background and other factors which may lead to educational disadvantage"

Similarly, the Organization for Economic Cooperation and Development (OECD) defined equitable tertiary education systems as: "those that ensure that access to, participation in and outcomes of tertiary education are based only on individuals' innate ability and study effort. They ensure that the achievement of education potential at tertiary level

\footnotetext{
1 Process, European Higher Education Area, ministerial conference Budapest-Vienna Declaration

2 Council conclusions of 11 May 2010 on the social dimension of education and training, 2010, p. 2

3 Ibid.
} 
is not the result of personal and social circumstances, including of factors such as socio-economic status, gender, ethnic origin, Immigrant status, place of residence, age, or disability" (OECD 2008, p. 14)4.

Innate ability and study effort. They ensure that the achievement of education potential at tertiary level is not the result of personal and social circumstances, including of factors such as socio- economic status, gender, ethnic origin, and immigrant status, place of residence, age, or disability"5.

\section{Methodology and main objectives of the study}

Information used in this study is based on different sources. For this purpose is explicated not only the experience and the previous studies of the authors, but also many other materials from Albanian and foreign authors. The analysis intends collecting information based on the knowledge and educational system implementation in private and public universities in Albania. Through the interviews we tried to identify some of the problems related with this process as how to issue conclusions for the necessary strategies for the future of the education. The integration of higher education systems in the Western world has led both to development of overall strategies for the organization of higher education institutions by public authorities, as well as to strategies by higher education institutions aiming to position themselves within emerging higher education systems. This article first asks whether these developments represent converging or path dependent trends before it sketches a conceptual point of departure for the analysis of the relationship between institutions in higher education systems based on the effects of integration on academic hierarchies and functional specialization. Then I discuss how recent attempts at integrating higher education systems in Europe as a process by which students learn to learn or by which they learn specific occupational skills. Thirdly, the development is situated in a wider context where the relationship between different types of institutions are considered in relation to the spread of an extended and more utility oriented concept of knowledge. Finally, I consider briefly some possible future developments based on how modern capitalist and public manager knowledge regimes constitute conditions for higher education integration.

The analysis showed that, at Albanian level, significant attention is devoted to making European Higher Education more equitable and inclusive. The interviews mainly contain structured and half-structured questions, with the intention to allow the freedom of expressing thoughts, assessments, comments and suggestions. These analyses are addressed to the high educational institutions, in different faculties of public and private universities.

\section{Background and Current Situation in Albania Education}

Higher education and scientific research in Albania are not yet up to international standards, progress seems to have been somewhat disappointing in the last 14 years. This paper aims to describe the main problems under three major groups: institutional framework, teaching and curricula, financial issues.

\subsection{Institutional Framework}

Institutional framework for higher education is out of time and the current laws do not provide an adequate basis for a modern system.

The first and most critical for Albania is that the higher education system is not sufficiently responsive to the future needs of society and the economy. Many aspects of higher education, especially in universities teaching style was not answered major changes that have occurred in the rest of Albanian society - in Europe and beyond. The institutional framework for system level tends to impair the sensitivity and responsiveness.

The second point is that the current system is more homogeneous and there is explicit recognition of the need for different universities have different missions. Current institutional framework does not reflect the difference of the mission, roles, and structure between institutions. Although there are currently some variations, a diversity not officially recognized, and this hinders development. The legal basis should be flexible to allow this diversity and even encourage it.

Regional universities in particular have a strong role in regional and local development actively encouraged not to give help local economies, for example through local service coverage. Moreover, some of them are too small to be able

${ }^{4}$ Eurydice, August 2011 Modernization of Higher Education in Europe: Funding and the Social Dimension European , p.14,

${ }^{5}$ Modernization of Higher Education in Europe: Funding and the Social Dimension European , p.8Eurydice, August 2011 
to operate efficiently as a university; any future development will be through the expansion of existing institutions rather than opening new ones.

Third, until recently, teaching (at the university) and research (Research Institutes) have been separated from each other. A group of experts has formulated proposals to reform the institutional terms. Their proposals are that the majority of research institutes or behave in a university where they were taken or under - the Minister. We are discussing these proposals and will soon take final decisions. As a result of the current framework, there is a clear strategy for the future direction of research.

The fourth point is that, in addition to teacher training, there are too few higher education-oriented professional guidance, there is little or diploma programs subdivision. This has been another factor that has limited the capacity of regional universities to increase their regional role in supporting local economies

The fifth point is that the general lack of ability to respond to the challenges is not entirely the fault of the universities because they do not have the necessary autonomy to operate effectively in the XXI century. As they lack internal governance and internal management needed to operate at the required level of autonomy, and accountability mechanisms associated with outsourcing. As a result, some powers are insufficient and some powers are used in a negative way. Management and accountability regarding autonomy should be closely linked to the institutional framework and the law.

An important aspect is that this lack of autonomy under the weight of rules and laws, with a large number of bodies, central government and non-government, with all the regulatory functions. A central involvement has so great impact on efficiency, innovation and higher education. These adjustments need to be streamlined and increase the level of autonomy.

Finally, we recognize that there are limited capacities within the Ministry of Education to develop strategic policies for higher education and research.

\subsection{Teaching and curriculum}

As teaching methods and curricula and content of most university courses do not meet the future needs of society and the economy. In terms of teaching methods and style, has a tendency to give students information by asking her memorization rather encouraged them to think and analyze. In terms of content, courses are often narrow and traditional, to follow a discipline and without modules that give students alternative choices and flexibility in what they study. Partly because of the shortcomings of teaching, many of our students studying abroad, thought about 8,000 students, of which only maybe $10 \%$ return home after their studies ${ }^{6}$.

Means, by which students enter university and Graduation use for this purpose, have changed many times in recent a year that has brought confusion. Already have stabilized this - although at some acknowledge that more changes are needed.

To ensure good teaching, academic staff should undertake a work of a kind "with specialization", it has usually been confused with "scientific research" (e.g. publications). In a small country like ours, research should be undertaken by a restricted minority - those who are able to provide specific funding for research through competition. Confusion between specialization and research has negatively influenced the promotion criteria; promotion criteria should be the same for all universities, but relate to mission (different) of a particular university. One consequence of the current homogeneity has been that many of the academic staff is pursuing $\mathrm{PhD}$, while specialization is only needed for teaching role (and to follow a PhD is a high cost for individuals and for the country).

"The changing nature of the global economy is also exerting new and powerful pressures on regional educational needs and capacity. The liberalization of trade policies coupled with the ICT revolution has allowed the emergence of global corporations characterized by weakening ties to regional or national priorities" 7

There has been insufficient investment in improving teaching, especially for very important point to change teaching methods. There are no arrangements for performance management in universities can be determined by academic staff that operate with outdated methods and thus benefit through training in modern program. There was a tendency that the qualifications (especially $\mathrm{PhD}$ ) are necessary to ensure the quality of teaching, and this is not true for a large part of the teaching in the first round - in fact these two points relate too little.

\footnotetext{
${ }^{6}$ www.mash.gov.al
}

${ }^{7}$ Ivar Bleiklie, 2005, Organizing higher education in a knowledge society, p.44 
In initial teacher training, curricula are overloaded for students and not determined in advance what courses of subjects are needed for an efficient teacher. Even in training courses for teaching practice monitoring is inadequate.

Quality assurance ${ }^{8}$ was initially introduced in 1999 with the establishment of the National Agency for Accreditation and develops its role and methods. Until now, there has been a proper assessment highlighted the vital issue of teaching methods and style, and no importance was given to correspondence or contingent despite doubling over the last decade.

\subsection{Financial issues}

In the literature on higher education two views are pitted against one another with regard to the development of higher education systems. One view emphasizes a number of international trends that have been observed over the last few decades and assumes that higher education systems will converge. International developments such as increased crossnational student mobility, the commoditization of teaching and research or the European 'Bologna process, will push higher education systems to become more uniform, less autonomous and more eager to please actual funders be they public authorities, private businesses or students. One should in other words expect them to acquire a number of common characteristics that neither of them had before (1994). ${ }^{9}$

We know that current levels of funding from the state budget are not sufficient for the improvement and development of our universities - even in the event of a more efficient use of resources that should result from an integration of research institutes with universities. The quality of some of the buildings, equipment and libraries is not up to international standards - although it is not realistic to think that they will behave in these levels quickly. Even the staff salary levels are lower than ideal; resulting in that staff undertakes other work, often at the expense of the quality of teaching performance.

In terms of investment within the existing system, there is no doubt that the most urgent need and most important investment is the investment for the development of teaching staff in universities to improve teaching methods in order to meet the future needs of students, and through them, the country needs to XXI century.

Current methods of funding, universities do not have the necessary flexibility to use the funds - this is an important aspect of autonomy and related universities need to have an internal management and external accountability better. Also, the current financial arrangements mean that universities have a small incentive to generate their income - and administrative provisions make it difficult to act in this direction. Furthermore, the amount that the state gives to every university does not count on an objective basis, particularly the cost of funds for salaries.

- Students are the main source of income for universities, but the current structure of tariffs differentiated levels leaves little rational basis in this regard. Also there is little transparency on how it is used specifically come naturally worries that paying students. The mechanism for supporting students with low incomes is better directed and fails to efficiently those who really need this support.

\section{Social dimension objectives of the Bologna process ${ }^{10}$}

In Leuven/Louvain-La-Neuve, the Bologna ministers made a commitment to "set measureable targets to widen participation and widening participation of under-represented groups in higher education, to be reached by the end of the next decade" 11.

Eurydice examined the social dimension in the European Higher Education Area (EACEA/Eurydice 2010, pp. $27 \mathrm{ff}$ ) and concluded that significant changes in higher education systems have taken place since 1999, but that challenges remain ${ }^{12}$. In particular:

$>$ the social dimension of higher education [...] is understood differently from one country to another;

$>$ very few countries have linked their policy on the social dimension to the Bologna commitment of raising the participation of under-represented groups to the point where the higher education population mirrors the overall societal distribution;

$>\quad$ very few countries have set specific targets to improve the participation of under-represented groups in higher education, and only about half of the Bologna countries systematically monitor their participation ${ }^{13}$.

\footnotetext{
${ }^{8}$ www.aaal.gov.al

${ }^{9}$ Gibbons et al., 1994; The New Production of Knowledge.

${ }^{10}$ Eurydice, August 2011 Modernization of Higher Education in Europe: Funding and the Social Dimension European , p.14

11 Leuven/Louvain-La-Neuve Communiqué, 2009

12 Eurydice, 2008. Higher Education Governance in Europe
} 
The analysis ${ }^{14}$ showed that, at European level, significant attention is devoted to making European Higher Education more equitable and inclusive. However, questions remain about the effects of these political declarations. In particular, what has been done at national level to make higher education systems more inclusive? Are funding systems structured in a way that supports the achievement of the stated social goals? This is particularly relevant in an area where the European Commission has no direct legal competence, but rather influences national developments through supportive action. Similarly, the Organization for Economic Cooperation and Development (OECD) defined equitable tertiary education systems as:"those that ensure that access to, participation in and outcomes of tertiary education are based only on individuals' 15

\section{Objectives of Albania Higher Education system}

Higher education and research should change if Albania will take its place alongside other European countries. Albania needs a better educated population and a skilled workforce in order to build a future society based on knowledge. For these reasons, education should be a priority, which should be analyzed objectives such as:

- To assist the development of society and to raise standards of democracy and civilization.

- To help economic development by preparing highly qualified workforce and helping regional development - to ensure a strong link with the labor market, this is one of the principles of the Bologna Agreement.

- To fulfill the aspirations of young people better opportunities for all those who could benefit from them - and to increase the proportion of young people entering higher education.

To meet these objectives, based on the needs of society, the higher education system will create, develop and transmit knowledge through teaching, research and service. The quality of our higher education needs to be improved significantly - especially through an effective system of quality assurance and accreditation.

\subsection{Dimensions of the system.}

There are two important political-economic concerns that may push such a development. The first concern is that the level of education in the population affects the competitiveness of a nation. Prevailing beliefs seem to indicate that in order to elevate the level of education one must raise academic standards as they are laid down by the most prestigious research universities. The logical implication of this line of reasoning is that the higher the ratio of doctoral degrees in a population, the better. The second concern is that higher education systems need to be flexible in order to be efficient. In addition to offering the possibility of specialization in specific disciplines, students should have the opportunity to combine a wide array of subjects from different disciplines within -whether they do this within one institution or by moving from one institution to another - as the economic situation and employment situation changes. This will make the institutions more efficient and the candidates they produce better adjusted to the needs of the labor market. In order to do this there must be a common degree structure and a common system of student evaluation and grading across all types of education. Until quite recently, however, there were clear distinctions both between categories of institutions such as research universities, liberal colleges and vocational colleges and between types of institutions within the same categories, such as e.g. teacher, engineering and nursing colleges. The degree systems were incompatible and credits not transferable. In order to address these concerns one has to develop common formal standards. ${ }^{16}$

To realize the objectives of development of the country requires an expansion of higher education full-time - but not the system in its current form. The expansion will be worth to place a reformed system of high quality. Reform is needed for system-as well as individual universities. Reforms will be planned and implemented as an integral part of any expansion.

The level of system expansion should be consistent with the terms of the demands and needs. There are two aspects to the demand side: the future needs of the labor market and the number of qualified students who wish to enter higher education. As an economy in transition, our labor market is far from stable. The National Development Plan has set three priority sectors for expansion: Tourism, Agro-industry (Agriculture and Fisheries) and exports in general. These

\footnotetext{
${ }^{13}$ Eurydice, August 2011Modernization of Higher Education in Europe: Funding and the Social Dimension European , p. 8

14 Leuven/Louvain-La-Neuve Communiqué, 2009, The Bologna Process 2020 - The European Higher Education Area in the new decade

15 OECD 2008, Tertiary Education for the Knowledge Society p. 14.

${ }^{16}$ Ivar Bleiklie, 2005 Organizing higher education in a knowledge society, p.35
} 
priorities should be reflected in approval for future extensions to the number of students. However, in 2005 only $6 \%$ of students were in programs of study as science, mathematics, computer science, engineering and construction ${ }^{17}$ compared with $25 \%$ in many countries in our region. We cannot say exactly how this figure should be, but the $6 \%$ rate is far from the region. What is need is a review and assessment of the situation to determine an appropriate level in science and engineering branches, this review will include the rational aspects of the labor market situation, as is done in other countries and the region.

Many graduates in the future will be employed in various types of private sector, many of which do not even exist today - and they can anticipate change jobs and occupations several times during their lifetime. The experience of other countries highlights two important points about how the system should respond to the future needs of the labor market. The first is that graduates should be prepared for the anticipated needs of the labor market for generic and transferable skills such as analysis skills, thinking, reasoning, communication and presentation. But this is not the main concern of the current methods in Albania. Although the labor market cannot identify these future needs in the present moment, we think it is the duty of the university to give direction to the labor market in these developments a knowledge-based economy. This will require new types of courses, but more importantly. It will require changes in teaching methods.

The second lesson to draw from other developing countries, not only in Central and Eastern Europe is an important requirement for future 2-year postgraduate courses such as professional degrees and other qualifications in subdivision (often part-time) to ensure technique skill level. This greater diversification will also provide an important stimulus to local, e.g. for small businesses and new industries to help in this way local economic growth. Currently there is little basis in this regard, in addition to several new courses set up at the University of Durres (Tourism), which suggests that there may be an opportunity and space for the private sector to provide such courses.

As the number of qualified candidates who wish to enter university, it is important not to risk the quality of the university system expanding faster than the increase in the number of eligible students. These targets are ambitious expansion. As part of this expansion will certainly affect the first, second and third - perhaps from universities in Tirana, a large part of the expansion will be in degrees and specialized courses (often two years). This will not only provide qualifications that are relevant to the labor market, with flexible curricula oriented industry, but should be even lower cost than a first full cycle. Regional universities are appropriate place to develop courses and increase enrollment by providing training and retraining courses to help local economies. Another potential space will be private institutions (accredited) with students paying fees or sponsored by employers.

This expansion should coincide and fueled by growth in the area of delivery. In particular, it is necessary to have a qualified academic staff appropriately, in appropriate areas, to be able to train the growing number of students. Current student-teacher ratio (about 25) is slightly higher than the EU average. Most academic staff will be to take on teaching role (mainly in the degree program and the first cycle) and thus should have a Master's Degree PhD but not necessarily, as some need to be involved in research. We think that is a realistic target for new staff (allowing those who intend Research). The correct balance between subject areas may not be known years in advance.

But the issue of teaching is more than a matter of academic staff numbers, few academic staff operate on such a method that develops skills in students, skills that will be needed in the future. To this point, it requires a significant investment in the development of existing academic staff, not just old professors - as well as training new staff.

A second factor in terms of what universities offer resources for the future physical plant and equipment. Currently the university premises are not used effectively for the entire week - and during the year, there are examples of areas lacking faculties and other faculties have too. A better organization of the use of space and classrooms will increase the possibility for a more efficient use of buildings and individual classes, all faculties should see that the premises and equipment belonging to the University as a whole and not individual faculty - regardless of how the have been funded at the time when they were created. With a more efficient use, a growing number of students can be done without increasing the space equivalent; some buildings are unquestionably in unacceptable conditions.

There are also issues related to the use of equipment, although it must be admitted that many of the devices are not appropriate for a modern teaching. No detailed information on the use of existing equipment or the degree of absenteeism. Any improvement of equipment provided in connection with improving the methods of teaching staff; the new equipment should be incentive to learn the use of new teaching methods.

The third and fundamental factor related universities that offer it as sufficient and adequate financial support is the future. The government is committed to double public funding for education in the next 5 years, but this is for recurrent

\footnotetext{
17 www.mash.gov.al
} 
costs, not expansion capital. Financial support from other sources, including private contributions and assistance from other countries, the cost will be determined and must be adapted to suit opportunity for financial resources.

\subsection{Differentiated missions of universities: Teaching, research and development}

Currently higher education system is built as if all universities were alike, but there should be no significant difference between them. It is needed to develop a strategy that recognizes the need for these differences between university mission, with its implications for the structure and functions, so that each university to more effectively serves the needs of the country.

\subsection{Differentiated missions}

Aspect of teaching in regional universities continue to focus on vocational education, particularly training for Basic Schools, as well as nursing, social work, business, legal assistants, etc.. Almost the whole of their degree courses will be only the first cycle - except possibly on teaching; Bologna Declaration shall prevent regional universities offer only the first cycle. But we hope in a significant increase of diplomas and other programs with specialization in specific regional universities, again this is not precluded from Bologna.

"Here the demand for education is staggering since in a knowledge economy, it is clear to all that this is the key to one's future security. Unless developed nations step forward and help address this crisis. Today we see a serious imbalance between educational need and educational capacity-in a sense, many of our universities are in the wrong place"18.

However we do not intend to limit only regional universities first cycle - this position is not rigid, as for both students and universities. For students in regional universities believe that in cooperation with leading universities and conceived to enable access to second cycle programs, provided they meet the standards required for entry threshold.

We believe that regional universities (and perhaps private) to be on top diploma to develop and field the subdivision and specialization are the main providers for them. Regional universities will thus become the main beneficiaries of funds for development and we will give for this purpose - to help the fees of these courses, so that will increase their earnings. National Accreditation Agency will develop new criteria for Quality Assurance programs for twoyear degrees.

Continuous focus and the expanded regional universities in the field of vocational education will reinforce the need for them to have a clear role in assisting economic and social development of their region. Being developed as a "Regional Development Center" with a focus on local needs and with stronger ties to the local community. Besides teaching role, local universities will have their identity and be more specific and more popular than now.

In addition to their teaching role, their role in economic and social development means that regional universities will offer consultancy, applied research and other services to the community and local businesses - that would help to disclose additional income. Potential major customers for these services will be local businesses, government bodies and government (central and local) and various donor organizations, all ministries and donors will be encouraged to use the services of universities....

Research strategy will serve as a basis for decisions on future program areas within which projects will be funded academic research. Academic research will be funded on project basis, as a result of competition and will be awarded based on merit. Funding for research will not include the salaries of academic staff research as the full cost of salaries will continue to be covered by the general resources of the process of distribution of funds from the budget.

Much of the academic research is believed to occur within three major universities in Tirana, which in the future will include various Research Institute. Some of these research institutes in universities will open up opportunities to rationalize research capacity across the country.

While regional universities will undertake work to apply to their local communities described above, each regional university will be able to compete for academic research projects if the capacity for research relevant: if it does not have any consideration special. Improving teaching and learning

Future needs of the country require three cycles standards - and specified degrees (the subdivision) - to be consistent with those of Europe; currently are not. To improve these standards requires the development of criteria to

18 Ivar Bleiklie, 2005Organizing higher education in a knowledge society, p.40. 
assess them. There are two main aspects of the standards, teaching methods and content; need a national policy to improve both - and universities will need time to make the required improvements.

\subsection{Teaching Methods}

Albania needs in the XXI century will be for people with flexible and adaptable skills of thinking, analysis, creativity and problem-solving abilities - as the economy and wider society. Providing these types of skills is the only change needed most important in the whole system of higher education that Albania will not lose in Europe. Certainly there will be a continuing need for specific professional knowledge, but more general capabilities of generating will become increasingly important, and for many graduates, they will be more valuable than knowledge of the specific areas.

However a small part of the current method of teaching in universities is designed to develop such skills to students. Largest current method aims to "facts" and not to use an interactive approach and focused on the student need to develop these skills. The whole nature of the relationship between individual students and academic staff need to be changed, in order to be interactive and based on discussions, thinking and development of ideas - not only for the transmission of facts. This is one of the most serious deficiencies in our system of higher education - and makes it three cycles - and specified degrees. To improve the quality of teaching, and teaching methods are the ways of realization to be changed. This change in teaching methods is extremely important to the future of our country than increasing the number of teachers who have PhD. Investments in the future for staff development should focus on this change.

But this change in teaching methods will be a challenge for most of the staff not only old professors who for years have used the same method and see no need for change. It is the duty of universities to find ways to develop academic staff and they must find the way how we can do this. There are some elements that a university can use in its plans:

Learning abroad: term exchanges with universities abroad (e.g. a semester) can be a cost effective way to develop teaching skills: Albanian staff goes overseas to pursue undergraduate lectures (or give) to see style of teaching practice; foreign staff invited here to give lectures to students and local staff to be present as observers. However care must be taken in selecting the University's foreign Staff returning from abroad: Any staff member who returns from abroad and is familiar with the new methods should use these in their lessons and to invite colleagues to attend as observersShort courses on teaching methods: Faculties (new) education in universities (see below) may be required to organize short courses on teaching methods.

Feedback from students: Students can be good judges of teaching methods used in their lessons, but would need training on specific aspects of teaching should be based on where and how to organize this feedback is the risk that they will simply give good reports for teachers with less demand. Managing staff performance: Universities should consider setting up a system of staff development for academic performance for each case, a critical part of which will be to evaluate teaching methods to try to development needs - and perhaps with a bonus reward for good performance. Promotion Criteria: For all universities, the promotion criteria should include the teaching performance as an important criterion, although the weight to be given will be different in accordance with the University's mission.

We need a special investment fund for universities to develop a specific strategy to improve teaching if planning to become cost-effective way. Accreditation Agency should pay greater attention to assessing teaching methods, teaching style and Quality Assurance process, the results of which will influence the distribution of the number of prospective students in faculties - and therefore funds for university

\subsection{Content of teaching}

It is not only the teaching methods and content of teaching that have become modern XXI century. Universities have begun to adopt a more modular course in the framework of the Bologna but a large part of the work was simply a repackaging of existing courses. It is important that universities understand that the main purpose of modular and Credit Transfer System is not merely administrative, but a benefit to students, to expand opportunities for them and to enable them real choice and transfer options (both within and between universities). To be beneficial for their students and in the context of fulfilling the requirements arising from Bologna, universities need to develop the required transfer system modularization, as for internal transfers and external ones behind.

Also, programs that are interdisciplinary study with a broad framework will become important in the future programs like "Engineering with Business Studies". Such programs do not require a new branch, but will be created as a result of joint work between the two faculties or universities, with the two deans responsible to sign the certificates to be issued. Faculty staff is expected to work in both faculties to such programs as part of their work in teaching (and not have 
special charge of second faculty). To develop such courses will need a forum within universities to discuss and develop ideas; it should be part of the preparation of the university governance and It will be valuable to universities turn for help foreign universities to develop inter-disciplinary courses. We will actively support the development of such programs; it may be through funding methodology or through a special fund initiator.

Familiarity with operating knowledge of computer science and English will be important for future students. Universities are expected to make preparations in these matters, taking into account the fact that some regional universities might need to "buy" from outside the university (e.g. from other universities or private organizations), to realize these preparations is need funds.

We are aware that in some cases the teaching curricula are outdated (especially in science), sometimes it is the result of equipment that is outdated and because staff is not updated with contemporary developments. We propose the creation of funds to bring modern amenities (such sufficient) for the purposes of teaching, but first we need objective information on the current situation. Unseasonable staff, we expect universities to conceive a process to highlight this phenomenon and provided training for this category.

\subsection{Strengthening governance}

\subsubsection{External accountability and internal management}

To respond to the challenges of the rapid changes in society and economy, modern universities need more autonomy from the government than at present. In the course of time, we intend to increase the level of autonomy of the universities, but this should answer the other a more robust governance arrangement for external accountability of universities and provisions to improve internal management. Universities will be given autonomy status based on the approved plans prepared by each university - that will be needed to meet predetermined criteria. There are four aspects of autonomy to universities for the future, the most important of which will be included in the university statute:

- academic autonomy - that academic freedom means not only individuals but also the university will be able to define innovative curricula, new courses and, in the context of quality assurance and funding constraints, starting or closing of courses and programs, this has implications (consequences) for the distribution of the number of students,.

- structural autonomy - which means that universities will be able to determine their internal structures for academic units (faculties, departments, etc.) and be able to adapt according to changing external conditions.

- administrative autonomy - which means that universities will be able to define itself in ways that are consistent with their mission - but also within the framework of national standards and in accordance with the positive experiences of transparency and internal accountability.

- Financial Autonomy - which means that universities will have the flexibility to determine the allocation of internal resources, on the basis of plans and a budget, and expenditure, with a budget ceiling of their own, this method brings consequences for the distribution of funds from state. Managing the meaning of the word is a relatively new concept for universities.

Key management aspects within a university associated with the following issues:

1. Definition and implementation of priorities and planning and budgeting processes Development of a comprehensive budget within a given total budget; Methods of distribution of income from domestic sources among competing priorities;

2. Financial monitoring and control, as well as at central university level;

3. Decisions on levels of financial delegation; Develop policies for teaching and other academic policies;

4. Nature and operations processes of internal quality assurance; Managing staff performance and load distribution;

Management structure, job descriptions and selection processes for senior management posts

5. (Rector, Vice / rectors, deans, chancellors); The processes of selection and appointment of other staff;

6. Applying a strong professional support for management (especially in financial matters).

For these and other management decisions, each university will need an internal Management Group. Management Group should have clear terms of reference and agenda and act with well-defined details that unless there are compelling reasons of confidentiality, should be made transparently available to the university community. This timelines for the autonomy of universities need to cover: a) routes will increase autonomy, b) development of external accountability and c) internal governance processes, but will also cover d) changes in the mode of financing and funding 
for universities. Changes required in terms of culture can be significant - and in some universities may take more time than in others. External assistances help is needed to develop management processes.

\section{References}

Bleiklie, I.,2005 Organizing higher education in a knowledge society.

Clancy, P., 2010. Measuring Access and Equity from a Comparative Perspective. In: H. Eggins ed., Access and Equity. Comparative Perspectives. Rotterdam/Boston/Taipei: Sense Publishers.

Council of the European Union. Council Resolution on modernizing universities for Europe's competitiveness in a global knowledge economy, 16096/1/07. Brussels: Council of the EU. [pdf] Available at: http://register.consilium.europa.eu/pdf/en/07/st16/st16096re01.en07.pdf [Accessed 24 June 2011].

EACEA/Eurydice, 2010. Focus on Higher Education in Europe 2010: The Impact of the BolognaProcess. Brussels: EACEA P9 Eurydice.

EACEA/Eurydice, 2010a. Gender Differences in Educational Outcomes: Study on the Measures Taken and the Current Situation in Europe. Brussels: EACEA P9 Eurydice.

EACEA/Eurydice, 2009. Higher Education in Europe: Developments in the Bologna Process. Brussels: EACEA P9 Eurydice.

EACEA/Eurydice, 2011. Adults in Formal Education: Policies and Practice in Europe. Brussels: EACEA P9 Eurydice.

European Commission, 2010. New Skills for New Jobs: Action Now. A report by the Expert Group on New Skills for New Jobs prepared for the European Commission. [pdf] Available at: http://ec.europa.eu/social/main.jsp?catld=568\&langld=en\&eventsld $=232 \&$ furtherEvents=yes [Accessed 26 August 2010].

European Commission, 2010a. European Disability Strategy 2010-2020. A Renewed Commitment to a Barrier-Free Europe, Commission staff working document accompanying the Communication from the Commission to the European Parliament, the Council, the European Economic and Social Committee and the Committee of the Regions. SEC (2010) 1323 final. Brussels: European Commission.

European Commission, 2008. Commission staff working paper accompanying the Report from the Commission to the Council on the Council Resolution of 23 November 2007 on Modernizing Universities for Europe's competitiveness in a global knowledge economy. COM (2008) 680 final. [pdf] Brussels: European Commission. Available at: http://ec.europa.eu/education/highereducation/doc/com/sec2719_en.pdf [Accessed 14 April 2011].

European Commission, 2006. Communication from the Commission to the Council and the European Parliament. Delivering on the Modernization Agenda for Universities: Education, Research and Innovation. COM(2006) 208 final. Brussels: European Commission.

Eurydice, 1999. Key Topics in Education. Financial Support for Students in Higher Education inEurope. Brussels: Eurydice.

Eurydice, 2007. Key Data on Higher Education in Europe. 2007 Edition. Brussels: Eurydice.

Eurydice, 2008. Higher Education Governance in Europe. Policies, structures, funding and academicstaff. Brussels: Eurydice.

Law $N^{\circ} 9655$, 11.12.2006 amended in 27.12.2007 and 07.07.2008 Law for High Education in Albanian Republic. Nr. 9832, date 12.11.2007

Leuven/Louvain-La-Neuve Communiqué, 2009. The Bologna Process 2020 - The European Higher Education Area in the new decade. Communiqué of the Conference of European Ministers Responsible for Higher Education, Leuven and Louvain-la-Neuve, 28-29 April 2009. [pdf] Available at: http://www.ehea.info/Uploads/Declarations/Leuven_Louvain-la- [Accessed 5 January 2011]

London Communiqué, 2007. Towards the European Higher Education Area: responding to challenges in a globalised world. [Online] Available at: http://www.ehea.info/Uploads/Declarations/London_Communique18May2007.pdf [Accessed 5 January 2011].

OECD, 2008. Tertiary Education for the Knowledge Society. Volume 2. Paris

OECD, 2008a. Tertiary Education for the Knowledge Society. Volume 1. Paris.

www.mash.gov.al

www.aaal.edu.al 